\title{
Functional mRNA half-lives in the marine Vibrio sp. S14 during starvation and recovery
}

\author{
NAN H. Albertson, ${ }^{*}$ Thomas Nyström and Staffan KJelleberg \\ Department of General and Marine Microbiology, University of Göteborg, Carl Skottsbergs Gata 22, \\ S-413 19 Göteborg, Sweden
}

(Received 30 March 1990; revised 16 July 1990; accepted 20 July 1990)

\begin{abstract}
The decay rate of the potential to synthesize proteins after inhibition of transcription with rifampicin (Rif) was analysed at different times of energy and nutrient starvation for the marine Vibrio sp. S14. The decline of protein synthesis following Rif treatment is due to the instability of mRNA and permits an estimate of the functional mRNA half-life. The half-life of the mRNA pool was found to increase 6-fold (from 1.7 to $10.3 \mathrm{~min}$ ) during a period of $24 \mathrm{~h}$ of total energy and nutrient starvation. To resolve whether the increase in the mean mRNA half-life was a result of the stabilization of the entire pool or if proteins expressed during starvation were translated from very stable mRNAs, the half-lives of specific mRNAs were measured. It was found that the half-lives of mRNAs common to both growing and starving cells were increased between 2- and 3-fold during a period of $24 \mathrm{~h}$ starvation, and that some starvation-specific proteins were encoded by extremely long-lived mRNAs (up to $70 \mathrm{~min}$ ). The possible role of stabilization of $m R N A$ as a mechanism to economize protein synthesis during starvation conditions is discussed
\end{abstract}

\section{Introduction}

In the marine environment, growth of some heterotrophic bacteria may often be limited by energy and nutrient availability (Morita, 1988). The long-term viability (in years) of marine heterotrophic bacteria subjected to starvation conditions has been demonstrated in laboratory microcosms (Morita, 1985; Kurath \& Morita, 1983): for example, the marine Vibrio S14 remains $100 \%$ viable (determined as c.f.u.) for 2 weeks in conditions of total energy and nutrient starvation (Albertson et al., 1990b; accompanying paper). Despite the absence of exogenous substrates, incorporation studies have shown that the overall rate of de novo protein synthesis in Vibrio S14 continues for extended periods and is easily measurable after $96 \mathrm{~h}$ of starvation at $5 \%$ of the rate at the onset of starvation (Nyström et al. 1986). It has also been demonstrated by pulse-labelling that many new proteins are expressed during starvation; of the 66 proteins that were found to respond to starvation conditions and were identified on two-dimensional gels, 40 continued to be synthesized after $24 \mathrm{~h}$ starvation (Nyström et al. 1989).

Several studies have been undertaken to elucidate what determines the viability of organisms in starvation

Abbreviation: Rif, rifampicin. conditions. The paramount importance of continuing protein synthesis to the survival of bacteria during adaptation to starvation conditions has been demonstrated by the severe loss in viability when cells are treated with protein synthesis inhibitors during the first hours of starvation (Reeve et al., 1984; Nyström et al., 1989). Considering the cost of a functioning proteinsynthesizing system (Ingraham et al., 1983), and that the synthesis of proteins is an absolute prerequisite for survival, bacteria from nutrient-poor environments would have evolved mechanisms to economize protein synthesis efficiently in the complete absence of exogenous substrates. There are two main strategies to synthesize large amounts of protein, that is, either to synthesize a large amount of mRNA, or to synthesize mRNA that is stable enough so that many proteins may be translated from one message. The latter strategy would appear to be more efficient for organisms that are adapted to life in nutrient-limited environments.

Differential control of mRNA stability in response to environmental changes has only been demonstrated in a few cases: the growth-rate-dependence of Escherichia coli ompA mRNA (Nilsson et al., 1984); the control of nif mRNA in response to oxygen, ammonium and temperature in Klebsiella pneumoniae (Collins et al., 1986), the increased level of $r p o H$ mRNA in response to high temperatures (Erickson et al., 1987), and the presence of 
long-lived mRNA during fruiting body formation in Myxococcus xanthus (Nelson \& Zusman, 1983). In the present study, the stability of the entire mRNA pool in growing and in energy- and nutrient-starved (up to $24 \mathrm{~h}$ ) cells of the marine Vibrio S14 was measured. To resolve whether the stabilization of the pool was due to the presence of very long-lived starvation-specific mRNA species, or to an increase in the half-life of all the messages found in the cells, the half-lives of mRNAs corresponding to specific proteins common to both conditions, and specific for starvation conditions were measured.

\section{Methods}

Cultivation and starvation conditions. The marine Vibrio S14 (CCUG 15956) used in this study has been described previously (Albertson et al., 1990a; Mårdén et al., 1987). S14 was grown on a complex marine medium (VNSS) to the exponential phase, washed, and resuspended in a nine salt solution (NSS) to $5 \times 10^{7}$ cells $\mathrm{ml}^{-1}$ as described previously, i.e. cells were starved for carbon, nitrogen and phosphorus sources (Nyström et al., 1986). Cells were recovered from starvation by adding concentrated glucose minimal medium directly to the starvation flask to give the following final concentrations per litre of starvation suspension: $4.0 \mathrm{~g}$ glucose, $2.2 \mathrm{~g}\left(\mathrm{NH}_{4}\right)_{2} \mathrm{SO}_{4}, 0.5 \mathrm{~g} \mathrm{~K}_{2} \mathrm{HPO}_{4}$.

Determination of pool $m R N A$ half-life. The half-life was determined as the decay rate of the potential to synthesize proteins after complete inhibition of the initiation of transcription by RNA polymerase by use of the antibiotic rifampicin (Rif). These experiments are meaningful only if the concentration of Rif used $\left(500 \mu \mathrm{g} \mathrm{ml}^{-1}\right)$ inhibits the rate of RNA synthesis with the same kinetics at each sample time. Control experiments were done to ensure this by measuring the residual RNA synthesis after the addition of Rif by pulse-labelling (10 s) with $\left[{ }^{3} \mathrm{H}\right]$ uridine and measuring the amount of radioactivity precipitable in ice-cold $5 \%(\mathrm{w} / \mathrm{v})$ trichloroacetic acid (TCA). To measure the half-life of the mRNA pool, subcultures were pulse-labelled for $2 \mathrm{~min}$ with $\left[{ }^{3} \mathrm{H}\right]$ leucine at $0,2,4,6,8$ and $10 \mathrm{~min}$ after the addition of $\mathrm{Rif}$. Incorporation was determined by measuring the TCA-precipitable radioactivity. These experiments were done at least twice to confirm reproducibility, and representative results are presented in the Figures.

Determination of specific $m R N A$ half-lives. These experiments were done similarly to those described by Pedersen et al. (1978) except that one-dimensional Coomassie-blue-stained gels were used. Briefly, subcultures at 0 and $24 \mathrm{~h}$ of starvation were pulse-labelled with $\left[{ }^{3} \mathrm{H}\right]$ leucine for $2 \mathrm{~min}$ at $0,2.5,5,7.5$ and $10 \mathrm{~min}$ after the addition of Rif. The pulse was terminated by adding 100-fold excess of nonradioactive leucine, and the cells were subsequently chilled on ice, centrifuged, and boiled for $3 \mathrm{~min}$ in a lysis buffer (Albertson et al., 1987). A reference culture was labelled with $\left[{ }^{14} \mathrm{C}\right]$ leucine during exponential growth for several generations (the starvation reference culture was also labelled between $20-24 \mathrm{~h}$ starvation), centrifuged, and boiled for $3 \mathrm{~min}$ in a lysis buffer. The ${ }^{3} \mathrm{H}$ - and ${ }^{14} \mathrm{C}$-labelled cell extracts were mixed and electrophoresed on $12-20 \%(w / v$, acrylamide) gradient SDS-PAGE gels and stained with Coomassie blue as described previously (Albertson et al., 1987). The relative synthesis rates of specific protein species in the presence of Rif was determined by measuring the ${ }^{3} \mathrm{H} /{ }^{14} \mathrm{C}$ ratio in a particular band. This ratio was divided by the ${ }^{3} \mathrm{H} /{ }^{14} \mathrm{C}$ ratio of the extract, resulting in the relative synthesis rate of a particular protein in comparison to the overall rate of protein synthesis. The rate of protein synthesis before the addition of Rif was determined by pulse-labelling with $\left[{ }^{3} \mathrm{H}\right] l e u c i n e$, and was used for normalization. The absolute rate of synthesis of a specific protein was determined by multiplying the relative synthesis rate of that protein by the rate of total protein synthesis at that given time according to Pedersen et al. (1978).

Determination of relative amounts of starvation-induced proteins. Samples from 0, 2, 5, 24 and $120 \mathrm{~h}$ starvation were lysed and separated by one-dimensional electrophoresis and stained with Coomassie blue as described previously (Albertson et al., 1987). The gels were analysed by densitometry as described by Nyström et al. (1988), and the relative amounts of the three starvation-induced proteins included in this study were expressed as a percentage of the total protein loaded on the gel.

\section{Results and Discussion}

Results from the control experiments showing that Rif was equally as effective in inhibiting the initiation of RNA synthesis during growth and during the starvation period studied are shown in Fig. 1. The kinetics of the inhibition of $\left[{ }^{3} \mathrm{H}\right]$ uridine incorporation were similar to those found previously in E. coli (Pato \& von Meyenburg, 1970). Since it has been shown that starved Vibrio S14 cells are more resistant to the effects of ampicillin than cells that are not starved (Nyström \& Kjelleberg, 1989), this control is especially important in these experiments.

The increase in the mean mRNA half-life between 0 and $24 \mathrm{~h}$ starvation is shown in Fig. 2. Since Rif inhibits the initiation of transcription by RNA polymerase, the changes in incorporation of $\left[{ }^{3} \mathrm{H}\right]$ leucine reflect the decay of mRNA that was synthesized prior to Rif addition. The increase in the mean mRNA half-life during starvation could be due either to a global stabilization of the mRNA pool (for example by decreased RNAase activity) or to the contribution of the mRNAs coding for starvationinduced proteins that could be very long-lived. To discriminate between these alternatives, we determined the functional half-lives of mRNAs coding for proteins found in both growing and starving cells, and also the half-lives of some mRNAs encoding starvation-induced proteins identified on one-dimensional gels. As can be seen in Table 1, there appears to be a global effect on mRNA stabilization during starvation since the halflives of mRNAs encoding proteins common to growth and starvation conditions increased 2-3-fold. When the functional mRNA half-lives of the starvation-induced proteins were examined, it was found that two of three such proteins were encoded by very long-lived mRNAs (Table 2). The relative abundance of these proteins is between 0.2 and $0.4 \%$ after $2 \mathrm{~h}$ starvation and the amount remained high or increased during a starvation period of $120 \mathrm{~h}$ (Fig. 3). The results presented in Tables 1 and 2 suggest that both of the two proposed explanations for an increase in the mean mRNA half-life, involving global and specific effects on transcript stability, may be involved in the starvation-induced increase in the mean mRNA half-life (Fig. 2). 


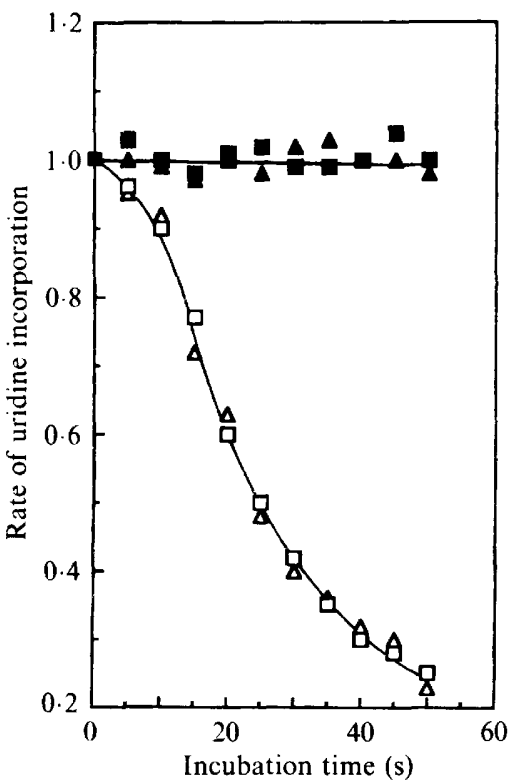

Fig. 1. Kinetics of RNA synthesis at the onset of starvation $(\square, \square)$ and after $24 \mathrm{~h}$ starvation $(\Lambda, \Delta)$ in the presence (open symbols) or absence (filled symbols) of $500 \mu \mathrm{g} \mathrm{Rif} \mathrm{ml}^{-1}$. Rates are given relative to that at zero time.
Table 1. Starvation-induced increase in the functional half-life of mRNAs encoding proteins common to growth and starvation conditions

Results shown are from at least two separate experiments, and the standard deviation is indicated.

\begin{tabular}{cccc}
\hline \hline Protein & $\begin{array}{c}\text { Approx. size } \\
\text { (kDa) }\end{array}$ & $\begin{array}{c}\text { Half-life at } \\
\text { onset of starvation } \\
\text { (min) }\end{array}$ & $\begin{array}{c}\text { Increase (-fold) } \\
\text { in mRNA half-life } \\
\text { after 24 h starvation }\end{array}$ \\
\hline A & 15 & $3 \cdot 15 \pm 0.35$ & $2.02 \pm 0.41$ \\
B & 21 & $4.7 \pm 0.7$ & $3.34 \pm 0.71$ \\
C & 25 & $3.08 \pm 0.59$ & $1.88 \pm 0.49$ \\
D & 33 & $2.25 \pm 0.75$ & $2.95 \pm 0.65$ \\
E & 40 & $5.35 \pm 2.15$ & $1.82 \pm 0.15$ \\
G & 80 & $3.8 \pm 0.2$ & $2.09 \pm 0.42$ \\
\hline
\end{tabular}

Table 2. Estimated functional half-lives of $m$ RNAs encoding starvation-induced proteins (stpt)

Results shown are from at least two separate experiments, and the standard deviation is indicated.

\begin{tabular}{lcc}
\hline \hline Protein & $\begin{array}{c}\text { Approx. size } \\
(\mathrm{kDa})\end{array}$ & $\begin{array}{c}\text { Estimated half-life } \\
\text { at 24 h starvation (min) }\end{array}$ \\
\hline stpt 1 & 210 & $71 \cdot 5 \pm 10 \cdot 3$ \\
stpt 2 & 190 & $25 \pm 3 \cdot 0$ \\
stpt 3 & 37 & $7 \cdot 5 \pm 0 \cdot 5$ \\
\hline \hline
\end{tabular}
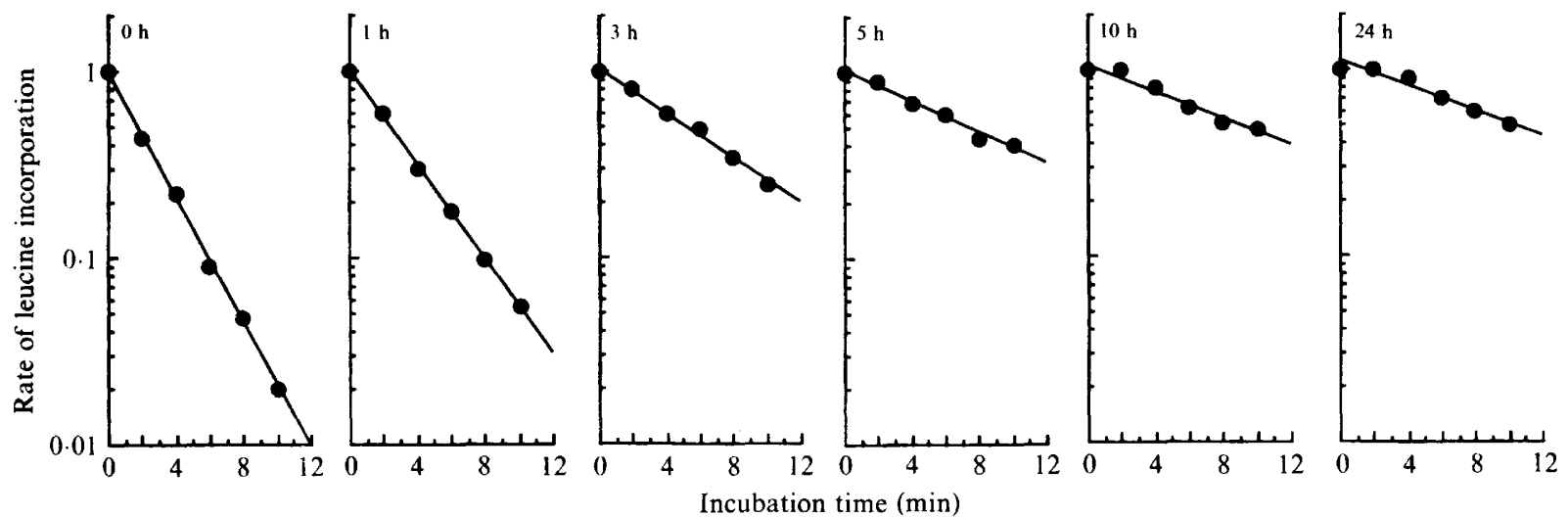

Fig. 2. Residual protein synthesis after inhibition of transcription with Rif at different times of starvation. At time zero, Rif $\left(500 \mu \mathrm{g} \mathrm{ml}^{-1}\right)$ was added, and at the indicated times samples were taken and the incorporation of $\left[{ }^{3} \mathrm{H}\right]$ leucine was measured. Rates are given relative to that at zero time; note that the scale is logarithmic.

Several models for the mechanisms of mRNA stability have been proposed (reviewed in Belasco \& Higgins, 1988). The stability of a given message depends upon its secondary structure and therefore its primary sequence. These characteristics will determine the susceptibility of a message to digestion by a combination of endonucleases and 3 '-exonucleases. The initiation of cleavage by endonucleases is not well understood; however, it has been shown that there is some site specificity involved since the stability of a specific mRNA is not proportional simply to its length (Gorski et al., 1985; Belasco et al., 1986; Petersen, 1987; Belasco \& Chen, 1988), and recently, the growth-rate-dependent stability of ompA mRNA was found to be regulated by site-specific endonucleolytic cleavages in the $5^{\prime}$-non-coding region (Melefors \& von Gabain, 1988). In contrast, the structures giving resistance to $3^{\prime}$-exonuclease attack are better understood. For several mRNAs, the removal of 


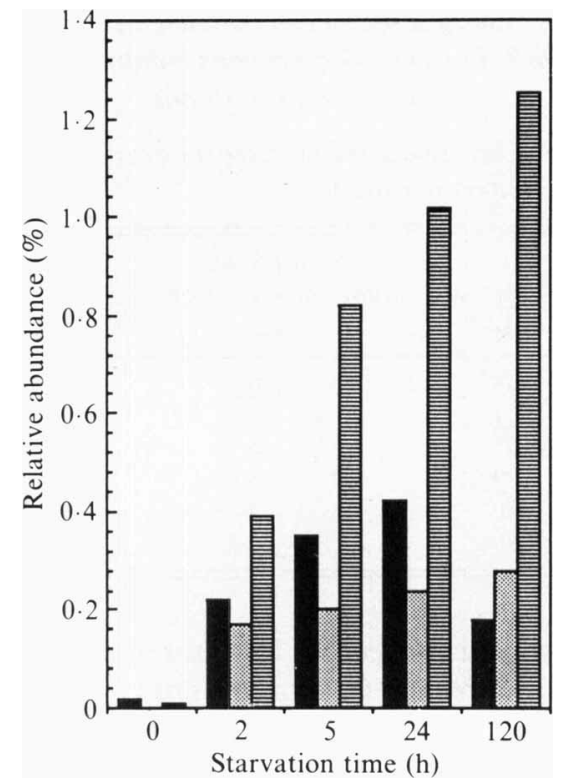

Fig. 3. Relative abundance of starvation-induced proteins (stpt) in comparison to total protein of cells at different times of starvation. Protein concentrations were determined by densitometry of Coomas-

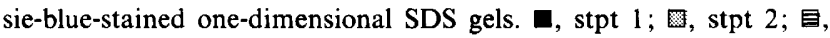
stpt 3 .

protective 3 '-stem-loop structures has resulted in mRNAs whose sensitivity to digestion is greatly increased (cf. Belasco \& Higgins, 1988).

The association of ribosomes with mRNA has also been claimed to have an effect on mRNA stability. For example, it has been proposed that ribosomes protect mRNA from degradation because mRNA stability increased when the elongation rate of ribosomes was slowed in response to the addition of fusidic acid (Pato $e t$ al., 1973) or halted in response to the addition of chloramphenicol (Pato et al., 1973; Schneider et al. 1978). The possibility that starvation may induce a decreased rate of ribosome elongation, and thus a stabilization of mRNA transcripts in Vibrio $\mathrm{S} 14$, has not yet been determined. The overall rate of protein synthesis in Vibrio S14 after $24 \mathrm{~h}$ starvation is about $10 \%$ of that of cells growing exponentially in a complex medium (Nyström et al., 1986). However, during amino acid starvation of $E$. coli, the decay rate of lac mRNA is unchanged, although the global rate of protein synthesis is reduced by $95 \%$, indicating that the mechanism for mRNA decay is the same (Kennell \& Simmons, 1972). Recent results indicate that the role of ribosomes in determining mRNA stability may not be so important since the most stable portion of the ompA transcript lies mainly in the $5^{\prime}$ - non-coding region, which is never covered by ribosomes (von Gabain et al., 1983).

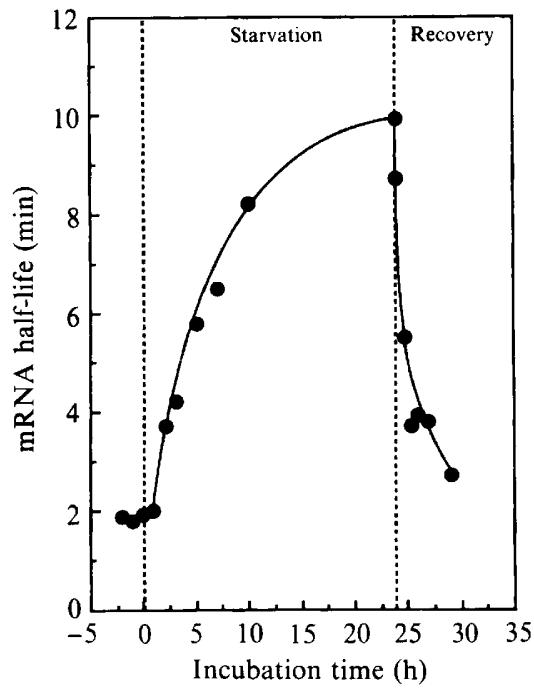

Fig. 4. Mean mRNA half-lives during starvation and recovery. Functional mRNA half-lives were determined as in Fig. 2.

Stanssens et al. (1986) found no differences in the decay rates of lac $Z$ transcripts bearing varying numbers of ribosomes.

We have also been interested in characterizing the recovery of Vibrio S14 from starvation conditions. When glucose minimal medium is added to cells starved for $24 \mathrm{~h}$, the relative rate of protein synthesis increases 5 -fold within minutes (Albertson et al., $1990 \mathrm{~b}$; accompanying paper). The effect of recovery conditions on the mean mRNA half-life was determined (Fig. 4). It was found that the stability of the mRNA pool is very sensitive to nutrient availability since the mean half-life decreased rapidly.

In conclusion, mRNA stability may be a factor contributing to the survival of micro-organisms in nutrient-limited environments. As discussed by Zusman et al. (1986) with respect to fruiting body formation in Myxococcus xanthus, prokaryotes that often experience long periods of nutrient deprivation may forego the advantage of short-lived mRNA and the ability to quickly adapt to changing environmental conditions in favour of longer-lived mRNA in order to conserve energy. The stability of mRNA in Vibrio S14 may be finely tuned with respect to energy and nutrient availability. This may aid the survival capacity of this organism in the marine environment by lowering the cost of the continuing protein synthesis that is central to the viability of this organism during starvation.

This study was supported by a grant from the Swedish Natural Science Research Council. 


\section{References}

Albertson, N. H., Jones, G. W. \& KJelleberg, S. (1987). The detection of starvation-specific antigens in two marine bacteria. Journal of General Microbiology 133, 2225-2231.

Albertson, N. H., Nyström, T. \& KJelleberg, S. (1990a). Exoprotease activity of two marine bacteria during starvation. Applied and Environmental Microbiology 56, 218-223.

Albertson, N. H., Nystrom, T. \& KJelleberg, S. (1990b). Macromolecular synthesis during recovery of the marine Vibrio sp. S14 from starvation. Journal of General Microbiology 136, 2195-2199.

Belasco, J. G. \& Chen, C.-Y. A. (1988). Mechanism of puf mRNA degradation: the role of an intercistronic stem-loop structure. Gene 72, 109-117.

Belasco, J. G. \& Higgins, C. F. (1988). Mechanisms of mRNA decay in bacteria: a perspective. Gene 72, 15-23.

Belasco, J. G., Nilsson, G., von Gabain, A. \& Cohen, S. N. (1986). The stability of $E$. coli gene transcripts is dependent on determinants localized to specific mRNA segments. Cell 46, 245-251.

Collins, J. J., Roberts, G. P. \& Brill, W. J. (1986). Posttranscriptional control of Klebsiella pneumoniae nif mRNA stability of the nifL product. Journal of Bacteriology 168, 173-178.

Erickson, J. W., Vaughn, V., Walter, W. A., Neidhardt, F. C. \& Gross, C. A. (1987). Regulation of the promoters and transcripts of $r p o H$, the Escherichia coli heat shock regulatory gene. Genes and Development 1, 419-432.

von Gabain, A., Belasco, J. G., Schottel, J. L., Chang, A. C. Y. \& COHEN, S. N. (1983). Decay of mRNA in Escherichia coli: investigation of the fate of specific segments of transcripts. Proceedings of the National Academy of Sciences of the United States of America 80, 653-657.

Gorski, K., Roch, J.-M., PrentKi, P. \& KrisCh, H. M. (1985). The stability of bacteriophage T4 gene $32 \mathrm{mRNA}$ : a $5^{\prime}$ leader sequence that can stabilize mRNA transcripts. Cell 43, 461-469.

IngRaham, J. K., MAALøE, O. \& NeIDHARDT, F. C. (1983). Growth of the Bacterial Cell. Sunderland, USA: Sinauer Associates Inc.

KenNell, D. \& Simmons, C. (1972). Synthesis and decay of messenger ribonucleic acid from the lactose operon of Escherichia coli during amino-acid starvation. Journal of Molecular Biology 70, 451-462.

KURATH, G. \& MORITA, R. Y. (1983). Starvation-survival physiological studies of a marine Pseudomonas sp. Applied and Environmental Microbiology 45, 1206-1211.

MÅrdén, P., NySTRöM, T. \& KJeLleberG, S. (1987). Uptake of leucine by a Gram-negative heterotrophic bacterium during exposure to starvation conditions. FEMS Microbiology Ecology 45, 233-241.

Melefors, Ö. \& vON GabaIN, A. (1988). Site-specific endonucleolytic cleavages and the regulation of stability of E. coli ompA mRNA. Cell 52, 893-901.

MORITA, R. Y. (1985). Starvation and miniaturisation of heterotrophs, with special emphasis on maintenance of the starved viable state. In Bacteria in Their Natural Environments, pp. 111-130. Edited by M. M. Fletcher \& G. D. Floodgate. London: Academic Press.
MORITA, R. Y. (1988). Bioavailability of energy and its relationship to growth and starvation survival in nature. Canadian Journal of Microbiology 34, 436-441.

Nelson, D. R. \& Zusman, D. R. (1983). Evidence for long-lived mRNA during fruiting body formation in Myxococcus xanthus. Proceedings of the National Academy of Sciences of the United States of America 80, 1467-1471.

Nilsson, G., Belasco, J. G., Cohen, S. N. \& von Gabain, A. (1984). Growth-rate dependent regulation of mRNA stability in Escherichia coli. Nature, London 312, 75-77.

Nyström, T. \& KJELlEbERG, S. (1989). Role of protein synthesis in the cell division and starvation induced resistance to autolysis of a marine Vibrio during the initial phase of starvation. Journal of General Microbiology 135, 1599-1606.

Nyström, T., MÅRDÉN, P. \& KJELleberg, S. (1986). Relative changes in incorporation of leucine and methionine during starvation survival of two bacteria isolated from marine waters. FEMS Microbiology Ecology 38, 285-292.

Nyström, T., AlberTson, N. \& KJelleberg, S. (1988). Synthesis of membrane and periplasmic proteins during starvation of a marine Vibrio sp. Journal of General Microbiology 134, 1645-1651.

Nyström, T., Albertson, N. \& KJelleberg, S. (1989). Physiological and molecular adaptation to non-growth by marine vibrios. In Recent Advances in Microbial Ecology, pp. 80-84. Edited by T. Hattori and others. Tokyo: Japan Scientific Societies Press.

PATO, M. L. \& von MEYenbURG, K. (1970). Residual RNA synthesis in Escherichia coli after inhibition of initiation of transcription by rifampicin. Cold Spring Harbor Symposia on Quantitative Biology 35 497-504.

Pato, M. L., Bennett, P. M. \& von Meyenburg, K. (1973). Messenger ribonucleic acid synthesis and degradation in Escherichia coli during inhibition of translation. Journal of Bacteriology 116, 710-718.

Pedersen, S., Reeh, S. \& Friesen, J. D. (1978). Functional mRNA half lives in E. coli. Molecular and General Genetics 166, 329-336.

Petersen, C. (1987). The functional stability of the lac $Z$ transcript is sensitive towards sequence alterations immediately downstream of the ribosome binding site. Molecular and General Genetics 209, 179-187.

ReEve, C. A., AMY, P. S. \& Matin, A. (1984). Role of protein synthesis in the survival of carbon-starved Escherichia coli K-12. Journal of Bacteriology 160, 1041-1046.

SCHNEIDER, E., BLUNDELl, M. \& KenNell, D. (1978). Translation and mRNA decay. Molecular and General Genetics 160, 121-129.

Stanssens, P., Remaut, E. \& Fiers, W. (1986). Inefficient translation initiation causes premature transcription termination in the $l a c Z$ gene. Cell 44, 711-718.

ZuSMan, D. R., Cumsky, M. G., Nelson, D. R. \& Romeo, J. M. (1986). Myxobacterial hemagglutinin: a developmentally induced lectin from Myxococcus xanthus. In Microbial Lectins and Agglutinins, pp. 197-215. Edited by D. Mirelman. New York: John Wiley. 